\title{
Accelerating Alzheimer's pathogenesis by GRK5 deficiency via cholinergic dysfunction
}

\author{
William Z. Suo ${ }^{1,2,3}$ \\ ${ }^{1}$ Laboratory for Alzheimer's Disease \& Aging Research, Veteran Affairs Medical Center, Kansas City, USA; \\ William.Suo@va.gov \\ ${ }^{2}$ Department of Neurology, University of Kansas Medical Center, Kansas City, USA \\ ${ }^{3}$ Department of Molecular \& Integrative Physiology, University of Kansas Medical Center, Kansas City, USA
}

Received 26 September 2013; revised 5 November 2013; accepted 13 November 2013

Copyright (C) 2013 William Z. Suo. This is an open access article distributed under the Creative Commons Attribution License, which permits unrestricted use, distribution, and reproduction in any medium, provided the original work is properly cited.

\section{ABSTRACT}

G protein-coupled receptors (GPCRs) mediate a wide variety of physiological function. GPCR signaling is negatively regulated by the receptor desensitization, a procedure initiated by a group of kinases, including GPCR kinases (GRKs). Studies using gene-targeted mice revealed that deficiency of a particular GRK member led to dysfunction of a highly selective group of GPCRs. In particular, for example, GRK5 deficiency specifically disrupts M2/M4-mediated muscarinic cholinergic function. Emerging evidence indicates that $ß$-amyloid accumulation may lead to GRK5 deficiency, while the latter impairs desensitization of M2/M4 receptors. Within memory circuits, M2 is primarily presynaptic autoreceptor serving as a negative feedback to inhibit acetylcholine release. The impaired desensitization of $M 2$ receptor by GRK5 deficiency leads to hyperactive M2, which eventually suppresses acetylcholine release and results in an overall cholinergic hypofunctioning. Since the cholinergic hypofunctioning is known to cause $B$-amyloid accumulation, the GRK5 deficiency appears to connect the cholinergic hypofunctioning and $B$-amyloid accumulation together into a self-amplifying cycle, which accelerates both changes. Given that the $B$-amyloid accumulation and the cholinergic hypofucntioning are the hallmark changes in the B-amyloid hypothesis and the cholinergic hypothesis, respectively, the GRK5 deficiency appears to bring the two major hypotheses in Alzheimer's disease together, whereas the GRK5 deficiency is the pivotal link. Therefore, any strategies that can break this cycle would be therapeutically beneficial for Alzheimer's patients.
Keywords: G Protein; Receptor; Kinase; Cholinergic; Alzheimer; Pathogenesis

\section{INTRODUCTION}

Alzheimer's disease (AD) affects 5.4 million Americans, and is projected to double by 2020 . AD is one of the most persistent and devastating dementias with little or no effective disease-modifying therapies. The cost of care for this particular patient population is disproportionately high since they require expensive support. According to the Alzheimer's Association, the cost of care was $\$ 183$ billion in 2010, which did not include 14.9 billion in services provided by unpaid caregivers. Therefore, advances with translational potentials are highly appreciable and desperately needed.

$\mathrm{AD}$ is a neurodegenerative disorder, clinically featured with progressive loss of memory and other cognitive functions, and pathologically featured with accumulation of senile plaques (SPs) and neurofibrillary tangles (NFTs) in limbic system and association cortices [1-4]. There have been many hypotheses for $\mathrm{AD}$, such as cholinergic hypothesis, amyloid hypothesis, tau hypothesis, glucose metabolism hypothesis, inflammatory hypothesis, vascular hypothesis, oxidative stress hypothesis, aluminium hypothesis, and etc. [5-15]. It is indeed that each hypothesis has its own supportive evidence and explains certain aspects of the disease process, yet none can see the forest for the trees. Before a unifying hypothesis is born and convincingly demonstrated, the field remains to be diversified and appreciate any and all innovative ideas with solid evidence. Numerous reviews have been written to summarize advances in relation to the mainstream hypotheses; this mini-review will instead briefly describe recent progress related to deficiency of $\mathrm{G}$ protein-coupled receptor (GPCR) kinase-5 (GRK5) in AD, and dis- 
cuss its relation to other hypotheses and the relevant future perspectives.

\section{CHARACTERISTICS OF GRK5 DISTRIBUTION AND FUNCTION}

\subsection{GRK5 and GRK Family}

GRK is a small family (7 members) of serine/threonine protein kinases first discovered through its role in receptor desensitization [16-18]. GRK family members can be subdivided into three main groups based on sequence homology: rhodopsin kinase or visual GRK subfamily (GRK1/GRK7), the $\beta$-adrenergic receptor kinases subfamily (GRK2/GRK3) and the GRK4 subfamily (GRK4/GRK5/GRK6). These kinases share certain characteristics but are distinct enzymes with specific regulatory properties.

All GRK members contain a centrally located 263 266 amino acid (a.a.) catalytic domain flanked by large amino- and carboxyl-terminal regulatory domains [19]. The amino-terminal domains share a common size $(\sim 185$ a.a.) and demonstrate a fair degree of structural homology. These characteristics have led to the speculation that amino-terminal domains may perform a common function in all GRK members, potentially that of receptor recognition. The primary function of GRK is to desensitize activated GPCRs, a negative regulative process, including phosphorylating the activated receptor, uncoupling the receptor-G-protein binding and initiating the receptor internalization. GRK phosphorylates GPCR primarily when the receptor is activated (agonist occupied). The receptor phosphorylation triggers binding of arrestins, which blocks the activation of $\mathrm{G}$ proteins, leading to rapid homologous desensitization [19-21]. As a result of the arrestin binding, the phosphorylated receptor is targeted for clathrin-mediated endocytosis, a process that classically serves to resensitize and recycle receptor back to the plasma membrane; or alternatively sorts the receptor to degradation pathway [22].

\subsection{GRK5 Expression and Distribution}

GRK5 was originally cloned using polymerase chain reaction (PCR) amplification of human heart and bovine circumvallate papillae cDNA libraries with degenerate oligonucleotide primers from highly conserved regions unique to the GRK family [23,24]. Among 7 GRK members, GRK 5 belongs to those that are widely expressed in various tissues, which is in contrast to GRK1, 4 and 7 that are confined to specific organs. For example, GRK5 mRNA is detectable in most tissues, whereas GRK1 and 7 are limited in retinal rods and cones, respectively, and GRK4 is only present in testis, cerebellum and kidney $[23,24]$. On the other hand, although GRK5 can be de- tected in most tissues, its levels vary significantly, with the highest levels in heart, lung, retina, placenta, and moderate levels in skeletal muscle. Brain, liver, pancreas, and kidney express very low levels of GRK5, with kidney having the least.

As compared to cardiovascular tissues, GRK5 content in brain is minimal $[23,24]$. This low content of GRK5 in brain is in part because majority of the cortical areas has little GRK5 expression, except for the limbic system [25]. The message of this kinase was found to be moderately expressed in several limbic regions namely the cingulate cortex, the septohippocampal nucleus, the anterior thalamic nuclei, dentate gyrus of Ammon's horn and the medial habenula. Notably within these sub-regions that express GRK5, the lateral septum was found to have the highest GRK5 message. Therefore, this characteristic distribution of GRK5 in brain discloses its unique functional relation to the limbic system.

In addition to the tissue-specific distribution patterns, increased GRK5 expression has been reported in relation to over-expression of tazarotene-induced gene 1 (a tumour suppressor gene) or $\alpha$-synuclein, and in adriamycin resistant tumor cells or hypothyroid animals, as well as in AngII-treated vascular smooth muscle cells and macrophage inflammatory protein-2 (MIP-2)-treated in polymorphonuclear leukocytes (PMNs) [26-31]. In general, there is a dearth of systematic studies that specifically address how GRK5 expression may be regulated under different circumstances, including the normal responses to various physiological stimuli and possible pathologic changes during aging and other disease conditions, such as $\mathrm{AD}$, drug abuse, cardiovascular disorders, and cancers.

\subsection{GRK5 Function}

As a GRK family member, the primary function of GRK5 is to desensitize activated GPCRs. Previous studies have shown that GRK5 regulates desensitization of many GPCRs, including $\beta$-adrenergic receptor ( $\beta \mathrm{AR})$, $\delta$-opioid receptor $(\delta$-OR), muscarinic receptors, angiotensin II Receptor (AngIIR), etc. [30,32-43]. Nonetheless, increasing evidence indicates that GRK5 can also phosphorylate certain none-GPCR substrates (Table 1) and thus affect their functions. For example, phosphorylation of $\alpha$-synuclein $[44,45]$ and tubulin [46] by GRK5 has been suggested to regulate their polymerization, and may therefore be related to neuronal function and possibly neurodegenerative disorders. Phosphorylation of p53 by GRK5 regulates p53 degradation [47], which implies a role of GRK5 in oncology. No matter if the substrates are GPCRs, this part of GRK5 function requires its kinase activity.

Beyond the kinase-dependent function, GRK5 has also 
Table 1. GRK5 substrates.

\begin{tabular}{|c|c|c|c|c|}
\hline Name & GPCR & Origin & Function & Reference \\
\hline AngIIR & Yes & Mouse & AngIIR desensitization, and hypertension & {$[30,32]$} \\
\hline$\beta \mathrm{AR}, \beta 1 \mathrm{AR}, \beta 2 \mathrm{AR}$ & Yes & Mouse & $\begin{array}{c}\text { Desensitization of } \beta \mathrm{AR}\left(\mathrm{G}_{\mathrm{i}}\right), \beta 1 \mathrm{AR} \text {, and } \beta 2 \mathrm{AR} \text {, related to } \\
\text { hypertension and heart failure }\end{array}$ & [32-36] \\
\hline$\delta$-OR & Yes & In vitro/cells & $\delta$-OR desensitization and drug abuse & [37] \\
\hline FSHR & Yes & In vitro/cells & FSHR desensitization and FSH signaling & {$[52]$} \\
\hline hSPR & Yes & In vitro & hSPR desensitization & [53] \\
\hline $\begin{array}{l}\text { M2 muscarinic } \\
\text { receptor }\end{array}$ & Yes & $\begin{array}{l}\text { Mouse/airway smooth } \\
\text { muscle/brain }\end{array}$ & $\begin{array}{l}\text { M2 muscarinic receptor desensitization: asthma or } \\
\text { pulmonary disease, and } \mathrm{AD}\end{array}$ & [38-43] \\
\hline PAR-1 & Yes & Endothelial cells & PAR-1 desensitization & [54] \\
\hline TSHR & Yes & Thyroid cells & TSHR desensitization & {$[55,56]$} \\
\hline a-synuclein & No & In vitro/cells/Lewy body & $\begin{array}{l}\text { a-synuclein oligomer formation and aggregation } \\
\text { in Parkinson's disease? }\end{array}$ & {$[44,45]$} \\
\hline HDAC & No & Cardiomyocyte/mouse & Myocardial hypertrophy & [57] \\
\hline Hip & No & In vitro/cells & CXCR4 internalization & [58] \\
\hline NFkB p105 & No & Macrophages/mouse & LPS-induced inflammation/TLR4 signaling & {$[59,60]$} \\
\hline P53 & No & Osteosarcoma cells & P53 degradation & [47] \\
\hline PDGFRß & No & In vitro & PDGFR $\beta$ desensitization & {$[61,62]$} \\
\hline Tubulin & No & In vitro/cells & Tubulin dimmer assembling into microtubules & [46] \\
\hline
\end{tabular}

Abbreviations: AngIIR, angiotensin II Receptor; $\beta \mathrm{AR}, \beta$-adrenergic receptor; $\delta$-OR, $\delta$-opioid receptor; FSHR, follicle-stimulating hormone receptor; HDAC, histone deacetylase; Hip, Hsp70 interacting protein; hSPR, human substance P receptor; PAR-1, thrombin receptor proteinase-activated receptor-1; PDGFR $\beta$, platelet-derived growth factor receptor- $\beta$; and TSHR, thyrotropin receptor.

been suggested to have kinase-independent regulatory function. For example, GRK5 inhibits nuclear factor $\kappa \mathrm{B}$ $(\mathrm{NF} \kappa \mathrm{B})$ transcriptional activity by inducing nuclear accumulation of $\mathrm{I} \kappa \mathrm{B}$ alpha $[48,49]$. GRK5 binds to Akt and negatively regulates vascular endothelial growth factor (VEGF) signaling [50]. Even more dramatically, GRK5 has been shown to contain a DNA-binding nuclear localization sequence, and may possess potential nuclear transcriptional regulatory function [51]. Therefore, it appears that GRK5 may have more divergent regulatory functions than just being a GPCR kinase.

\section{GRK5 DEFICIENCY AND ITS PATHOLOGICAL CONSEQUENCES}

\subsection{GRK5 Deficiency}

Although the dynamic regulation of GRK5 expression remains to be systematically investigated, scattered reports have indicated that GRK5 down-regulation may be associated with prolonged platelet-derived growth factor receptor- $\beta$ (PDGFR $\beta$ ) signaling, and treatments with gonadotropin-releasing hormone $(\mathrm{GnRH})$, thyroid stimulating hormone (TSH), morphine, or lipopolysaccharide (LPS) [31,55,62-64].

Even if the tGRK5 levels remain normal, the membrane or functional GRK5 deficiency could occur due to reduced membrane-associated GRK5 (mGRK5) levels $[40,65]$. Given that desensitizing membrane-integrated
GPCRs is the primary function of GRK, the kinase itself has to be physically associated with membrane to execute such a function. At physiological condition, GRK5 is primarily plasma membrane-associated by binding to phosphatidylinositol-4, 5-bisphosphate (PIP2) and phosphoserine (PS), and is ready to act when GPCRs are activated by their agonists $[19,20]$. In certain circumstances, however, the balance of the binding force for GRK5 between membrane (e.g., PIP2) and cytosol (e.g., $\mathrm{Ca}^{2+}$ / Calmodulin) can be disrupted, which may cause translocation mGRK5 to cytosol [65]. For example, in cultured cells, A $\beta$ can cause rapid (within minutes) GRK5 membrane disassociation and lead to functional mGRK5 deficiency $[40,66,67]$. Therefore, GRK5 deficiency may be caused by either decreased grk5 gene expression or reduced membrane distribution of the GRK5 protein, or both.

\subsection{Loss-of-Function in GRK5 Deficiency}

As described above, accumulating evidence indicates that GRK5 may have multiple regulatory roles in addition to primarily functioning as a GPCR kinase. Previous studies have suggested that functional redundancy exists between the seven GRK members in phosphorylating different GPCR substrates. In fact, some may even suspect that there might be little or no specificity among the GRK members, mainly due the fact that seven or so 
GRK members are responsible for regulating hundreds to thousands of GPCRs [20,65]. For the latter suspicion, studies using GRK knockout (KO) mice have generated unambiguous and convincing results that illustrate selective loss-of-function for each particular GRK member in vivo. For example, the mice deficient in GRK2, 3, 5 and 6 display selectively impaired desensitization of adrenergic, odorant, muscarinic, and dopaminergic receptors, respectively [38,68-70]. While recognizing the selective loss-of-function, many of the known functions of a GRK member are indeed not affected by the absence or deficiency of this GRK member, which on the other hand proves the redundancy or compensation between different GRK members. In the case of GRK5 deficiency, for example, the selective loss-of-function is evidenced only for muscarinic, but not for adrenergic or opioid receptors [38]. Nonetheless, many known GRK5 functions (i.e., those listed in Table 1) have not been specifically studied to include/exclude as the part of functional loss in relation to GRK5 deficiency. Therefore, it is possible that other functional loss caused by GRK5 deficiency, in additional to the impaired muscarinic receptor desensitization, remains to be discovered.

Interestingly, the loss-of-function caused by GRK5 deficiency on muscarinic receptor desensitization is receptor-subtype selective. To date, five muscarinic acetylcholine (ACh) receptor subtypes have been identified, with M1, M3, and M5 receptors being $\mathrm{G}_{\mathrm{q} / 11}$-coupled, and $\mathrm{M} 2$ and $\mathrm{M} 4$ receptors being $\mathrm{G}_{\mathrm{i} / \mathrm{o}}$-coupled [71]. GRK5KO mice, when challenged with non-selective muscarinic agonists, display augmented hypothermia, hypoactivity, tremor, and salivation, as well as antinociceptive changes [38]. These behavioural changes are typical M2 and/or M4 receptor-mediated functions, according to the findings from muscarinic receptor subtype $\mathrm{KO}$ mice $[71,72]$. Therefore, although without molecular evidence, Gainetdinov et al. speculated in the original report that GRK5 deficiency primarily affected the desensitization of M2 subtype of muscarinic receptors (M2R), based on the behavioural changes in the GRK5 KO (GRK5KO) mice [38]. Going further, we demonstrated that GRK5 deficiency led to reduced hippocampal ACh release that could be fully restored by blocking presynaptic M2/M4 aotoreceptors [42]. Moreover, non-selective muscarinic agonist-induced internalization of muscarinic receptors was primarily impaired for M2R, partially for M4R, but not for M1R. This study provided the molecular evidence that confirmed the earlier speculation of the subtypeselective effect of GRK5 deficiency on the inhibitory G protein-coupled $\mathrm{M} 2 \mathrm{R}$ and $\mathrm{M} 4 \mathrm{R}$, and revealed that the immediate pathophysiological consequence of GRK5 deficiency was the reduced ACh release (Figure 1).

\subsection{Pathologic Impact of GRK5 Deficiency}

Beyond the reduced ACh release, what pathologic im-

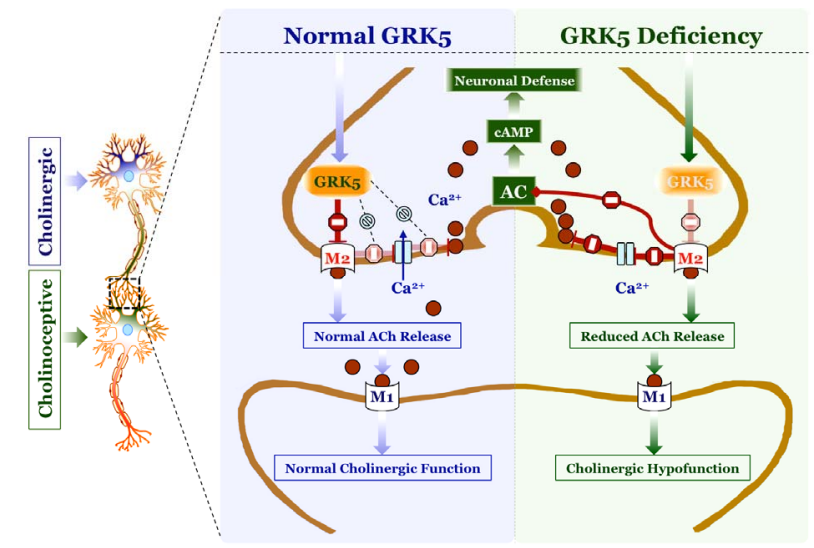

Figure 1. Schematic diagram of molecular interactions between GRK5 and muscarinic receptors. The selective impact of GRK5 deficiency on presynaptic M2, but NOT postsynaptic M1, determines its major impact is on the side of presynaptic cholinergic neurons, whereas its impact on the postsynaptic cholinoceptive neurons is limited to the indirect effects of the reduced ACh release. For its presynaptic impact, GRK5 deficiency leads to hyperactive M2 autoreceptor, which may not only inhibit ACh release but also persistently suppress adenylyl cyclase (AC) activity. The latter may impair the intrinsic defense mechanisms and increase the cholinergic neuronal vulnerability to degeneration.

pact may GRK5 deficiency impose to AD? The evidence in this line of work was initially obtained primarily from GRK5KO mice.

We have mentioned that GRK5 may have multiple functions that could be either kinase-dependent or independent [65]. Of note, the GRK5KO mouse was created by targeted deletion of exons 7 and 8 of the murine grk 5 gene [38]. It was predicted that this mouse should produce a transcript encoding a peptide that contains 194 amino acid (a.a.). This speculative peptide should include the N-terminal a.a. 1 - 178 of the native GRK5 protein and an extra fragment of 16 novel residues. Given that the RH domain of GRK5 locates at a.a. 50 - 176, this means that the GRK5KO mice are only deficient in the kinase-dependent function of GRK5, while the kinase-independent or RH domain-dependent GRK5 function remains unaltered. In other words, the phenoltypes revealed in the GRK5KO mice are irrelevant to the recently proposed RH domain-dependent GRK5 function $[48,49]$ or any other functions of GRK5 that are dependent upon the N-terminal of 1 - 178 a.a. In addition, compared to other AD mouse models, no genetic modifications were made to those commonly known AD-relevant genes, such as $\beta$ APP, presenilins, tau, or apolipoprotein $\mathrm{E}$, etc. Therefore, the phenotypes of these mice are solely caused by the loss or lack of the GRK5 kinase activity.

The initial characterization of the GRK5KO mice revealed that the young mice exhibited mild spontaneous hypothermia as well as pronounced behavioural supersensitivity (i.e., hypothermia, hypoactivity, tremor, Sali- 
vation, and antinociception) upon challenge with the non-selective muscarinic agonist oxotremorine [38]. Our later characterization in the aged (18 months), unchallenged mice discovered that the homozygous, but not the heterozygous, GRK5KO mice displayed significant shortterm (working) memory deficit, along with hypo-alertness [41].

At pathological level, the most prominent change was the increased swollen axonal clusters (SACs) [41]. Interestingly, this hallmark pathologic change in GRK5KO mice primarily affected hippocampus. In the advanced cases, it also affected the brain regions of piriform cortex, amygdaloid and anterior olfactory nuclei, while most of other brain regions were free of such pathological structures. We have mentioned that physiological GRK5 message expression in the brain is limited to the limbic system [25]. Therefore, it seems that the sub-regions where the SACs occur coincidently overlap with the sub-regions where GRK5 message is enriched or where these neurons are projected. It remains to be established mechanistically that if such a coincidence underlies the different aspects of the same mystery.

Beyond the axonal defects (SACs), we also found the decreased synaptic proteins (SNAP-25, synaptotagmin, and growth-associated protein-43) and muscarinic receptors (M1R and M2R), as well as increased soluble $A \beta$ and tau phosphorylation levels in hippocampus of the aged GRK5KO mice [41]. Moreover, the amnestic mild cognitive impairment (MCI) in these mice was positively correlated with the number of SACs and negatively correlated with the levels of M2R in the hippocampus, indicating that there exist certain internal relations among these changes in this animal model. It is worth noting that there were barely any observable senile plaques (SPs) or inflammatory changes, except for a few "micro" plaques captured under electronic microscope that showed fibrillar $\mathrm{A} \beta$-like structures and degenerating axonal components wrapped by reactive astrocytes. In particular the lack of inflammation in this model was somewhat contrast to our earlier expectations, given that the initial in vitro observation of $A \beta$-induced GRK5 deficiency was performed in microglial cells [40]. While analysing the possible reasons, we attributed the negative inflammatory reactions in this mouse to the fact that there was a lack of significant extracellular $\mathrm{A} \beta$ fibrils and/or any other inflammatory initiators, whereas the GRK5 deficiency can only play as an amplifier [41].

In order to verify these speculations, we crossbred the GRK5KO mice with Tg2576 mice that over-express the Swedish mutant human $\beta$ APP [73]. The produced heterozygous GRK5 deficient APP mice are referred to as GAP mice hereafter, although they were previously referred to as GRK5KO/APPsw double mice $[43,74]$. Stu- dies in 18-month old GAP mice revealed significantly exaggerated brain inflammatory changes, including microgliosis and astrogliosis, as compared to those in the age-matched Tg2576 (APPsw) mice [74]. We have mentioned above that GRK5KO mice showed no inflammatory changes [41], whereas the GAP mice displayed exaggerated inflammation, much worse than Tg2576 mice. As predicted earlier, the GRK5 deficiency indeed amplified the brain inflammation triggered by $\mathrm{A} \beta$ fibrils that are resulted from over-expression of the mutant human APP.

In respect to the underlying mechanisms, we have previously speculated that GRK5 deficiency may lead to impaired desensitization of one or more GPCRs that are involved in the fibrillar $\mathrm{A} \beta$-triggered inflammatory reactions $[65,74]$. The latter could include a score of GPCRs, such as formyl chemotactic receptor 2 (FPR2 or FPRL-1) [75,76], C3aR and C5aR anaphylatoxin receptors [77], and CCR, CXCR, and CXCXR chemokine receptors [78]. In addition, we did mention another possible explanation, which was the increased $\mathrm{A} \beta$ production itself [65]. Our latest data indicated the latter predication (the increased $\mathrm{A} \beta$ rather than the impaired inflammatory GPCR desensitization) is likely to be truth. First of all, none of the aforementioned inflammatory GPCRs was found to be affected by GRK5 deficiency. Secondly, we found that not only soluble $\mathrm{A} \beta$ production but also the fibrillar $\mathrm{A} \beta$ burden (both plaque number and area) were significantly increased in the GAP mice. Moreover, the increased A $\beta$ accumulation long preceded the exaggerated inflammation in the GAP mice [43]. In fact, our further analysis of the pooled data revealed that there exist strong positive correlations between the fibrillar $\mathrm{A} \beta$ burden and the gliosis in the GAP mice (Figure 2). Therefore, it becomes clear now that the exaggerated inflammation in the GAP mice occurs only after and is a consequence of the increased fibrillar $\mathrm{A} \beta$ deposits.
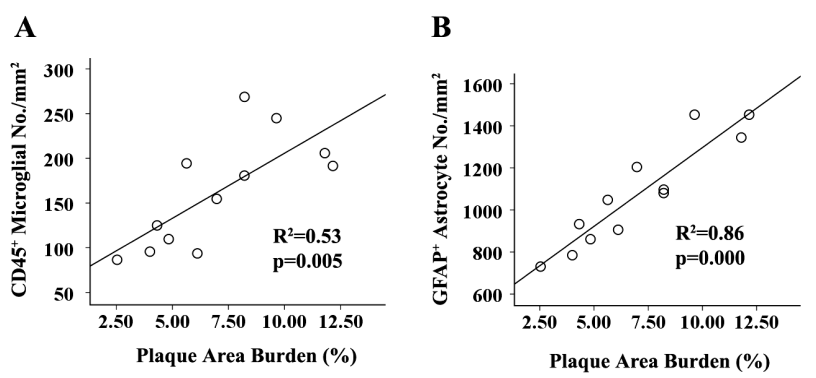

Figure 2. Correlation between $\mathrm{A} \beta^{+}$plaque burden and gliosis in the GAP mice. Significant linear correlations of $\mathrm{A} \beta^{+}$plaque area burden with $\mathrm{CD}_{4} 5^{+}$microglial (A) and $\mathrm{GFAP}^{+}$astrocyte (B) cell numbers in hippocampus of the GAP mice were shown as indicated. The analyses used pooled data from 18 months old female GAP and control Tg2576 mice with a sample number $\geq 12$. 


\section{MECHANISTIC LINKS BETWEEN MOLECULAR EVENTS DRIVEN BY GRK5 DEFICIENCY}

\subsection{Cholinergic Dysfunction and ß-Amyloidogenesis}

The pathologic impact of GRK5 deficiency in the GAP mice has now come to a simple point: the increased A $\beta$ production; whereas the immediate pathophysiological consequence of GRK5 deficiency is reduced ACh release [42]. Is there an internal relation between these changes? In this regard, our latest study untangled their relations [43]. We found that GRK5 deficiency altered $\beta$ APP processing in favour of $\beta$-amyloidogenic pathway, which was mediated by the impaired cholinergic activity.

From the perspective of phenomenon, we have observed and reported previously in the GRK5KO mice that the GRK5 deficiency promoted soluble A $\beta$ accumulation [41]. Perhaps because that it was murine $\mathrm{A} \beta$, we failed to observe significant fibrillar $\mathrm{A} \beta$ deposit in the GRK5KO mice. In the GAP mice, however, we found excessive $\mathrm{A} \beta$ accumulation, not only the soluble form, but also the fibrils deposited in the plaques. Comparatively, the total $\mathrm{A} \beta$ burden in the GAP mice at 18 month old was roughly doubled than that in $\mathrm{Tg} 2576$ mice at the same age [43]. Therefore, there is no question that GRK5 deficiency promotes $\mathrm{A} \beta$ accumulation. As for the relevant mechanism, we demonstrated that there was increased secreted APP $\beta$ fragment without change of the full length APP in the GAP mice, indicating there was an increased $\beta$-amyloidogenic APP processing in this animal model. In an acute experimental model, moreover, we also measured the dynamic change of interstitial fluid (ISF) $\mathrm{A} \beta$ in hippocampus of the mice. We found that the ISF A $\beta$ levels decreased when $\operatorname{Tg} 2576$ mice were challenged with novel object introduction (NOI) while this ability was retarded in the GAP mice. What interesting was that this difference between the GAP and Tg2675 mice was completely corrected by selective M2 antagonization, which clearly linked the increased $\mathrm{A} \beta$ production in the GAP mice to a cholinergic dysfunction, or more specifically to the presynaptic M2 hyperactivity that we previously described $[43,65]$.

The impaired desensitization of M2R is so far the only demonstrated molecular functional loss after GRK5 deficiency [38,42]. It is known that M1, M2 and M4, but not M3 and M5, are enriched in hippocampus, with M2/M4 being primarily presynaptic autoreceptors to negatively regulate $\mathrm{ACh}$ release in hippocampal memory circuits $[79,80]$. Therefore, once presynaptic M2R or M4R is activated, it is conceivable that the M2/M4 signalling will be prolonged, if there is GRK5 deficiency. This prolonged presynaptic M2/M4 autoreceptor signalling was referred to as presynaptic cholinergic hyperactivity
$[42,43,65]$. The best-known effect of the presynaptic cholinergic hyperactivity is the reduced ACh release [42], which in turn leads to postsynaptic cholinergic hypoactivity, including postsynaptic M1 hypoactivity. In fact, postsynaptic cholinergic hypoactivity (reduced ACh) has been previously shown to promote the $\beta$-amyloidogenic APP processing and A $\beta$ production [81-85]. Therefore, it is no surprise that blocking the presynaptic M2R and the prolonged M2 signalling completely restored the ability for the GAP mice to down-regulate the ISF $\mathrm{A} \beta$ production.

Aside from the increased $\mathrm{A} \beta$ accumulation and the subsequently exaggerated inflammation, another prominent pathologic change associated with GRK5 deficiency is the axonal defects and the reduced synaptic proteins and muscarinic receptors [41]. It remains to be established that whether the observed axonal defects and synaptic degenerative changes are cholinergic and/or cholinoceptive selective. Should it be the case, which is likely, the axonal defects and synaptic degenerative changes could be closely related pathologic events. There is no direct evidence suggesting that these pathologic changes are resulted from the presynaptic cholinergic hyperactivity, but supportive evidence certainly exists. For example, previous studies suggested that signaling of M1, M3 and M5, but not M2 or M4, appears to be anti-apoptotic [86]. M1 signaling was shown not only to inhibit $\beta$-amyloidogenic APP processing but also to decrease tau phosphorylation in vitro $[81,87,88]$. Therefore, M1 signalling is generally characterized as "cholinergic protective". On the other hand, M1 and M2 are typical Gq and Gi-coupled receptors, respectively, and often mediate distinct or even opposing signals [89,90]. M2 signalling is known to reduce cAMP level [89,90], and down-regulate protein kinase A (PKA) activity, a vital signalling pathway for cell survival and apoptotic resistance [91-96]. Maybe more relevant to axonal defects and synaptic degeneration, PKA phosphorylates and inactivates glycogen synthase kinase 3 (GSK3) to facilitate glucose metabolism and cell/neurite growth [97-100]. In the case of M2 hyperactivity, PKA will be persistently inhibited. In this case, GSK3 will be released from their complex, and become dephosphorylated and activated. The latter, especially GSK $3 \beta$, which is also known as tau protein kinase-1 (TPK1), is one main cause of tau hyperphosphorylation [101]. Tau hyperphosphorylation destabilizes microtubules and renders itself more prone to aggregation $[102,103]$, which can contribute to axonal defects. Moreover, GSK $3 \beta$ can also phosphorylate kinesin light chain (KLC), which leads to detachment of the kinesin motor from the cargo, thus preventing further transport of cargo and resulting in axonal swellings [102,104,105]. Therefore, if M1 signalling is "cholinergic protective", then M2 signalling appears to be "cho- 
linergic destructive", at least when it is prolonged. In the case of GRK5 deficiency, both presynaptic M2 hyperactivity (destructive) and postsynaptic M2 hypoactivity (less protective) would be detrimental to the cholinergic neuronal system (see Figure $\mathbf{3}$ for schematic illustration of the hypothesis).

\subsection{GRK5 Deficiency Links the Amyloid and Cholinergic Hypotheses Together}

Despite various views on detailed causes and processes of AD, two major hypotheses have driven pharmaceutical research of $\mathrm{AD}$ in recent three decades: the amyloid hypothesis and the cholinergic hypothesis [106]. The cholinergic hypothesis states that central cholinergic neuronal dysfunction is largely responsible for the cognitive decline in $\mathrm{AD}$ [5]. The amyloid hypothesis proposes that $\mathrm{A} \beta$ is the central pathogenic molecule in $\mathrm{AD}$ [6]. Although the details of these two hypotheses may evolve over time with increasing insights into disease pathogenesis, the principal concepts of these distinct hypotheses appear to stand solidly [6,106-112].

First, $\mathrm{A} / \beta$ is one of the main causes for mGRK5 deficiency in AD [40]. Once GRK5 is deficient, it selectively impairs desensitization of presynaptic M2/M4 autoreceptors, which leads to presynaptic cholinergic hyperactivity and the subsequent postsynaptic cholinergic hypoactivity. The latter, as the key component of the cholinergic hypothesis, further accelerates $\mathrm{A} / \beta$ production. Therefore, these studies directly connect A $\beta \rightarrow$ GRK5 deficiency $\rightarrow$ cholinergic dysfunction $\rightarrow \mathrm{A} \beta$ into a selfpromoting loop or vicious cycle. In this vicious cycle, A $\beta$ and cholinergic dysfunction each can serve as the causes

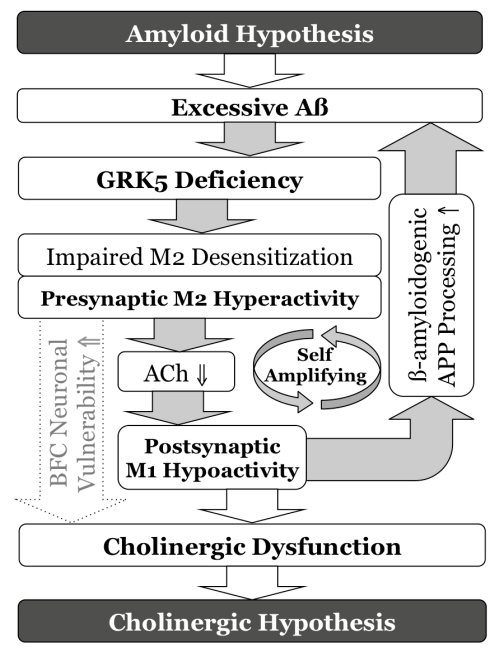

Figure 3. Schematic illustration of relations of GRK5 deficiency to the $\beta$-amyloid and the cholinergic hypotheses. BFC, basal forebrain cholinergic. and consequences, while GRK5 deficiency is the pivotal mediator (Figure 3). Given the dominating importance of both amyloid and cholinergic hypotheses in $\mathrm{AD}$, more efforts should be directed to studies of GRK5 deficiency that has been overlooked in the past.

It is worth noting that cholinergic dysfunction is a relatively broad term describing the deficiency of neurotransmitter $\mathrm{ACh}$ at cholinergic terminals. Cholinergic dysfunction in $\mathrm{AD}$, according to the cholinergic hypothesis, is characterized by cholinergic hypofunction or a reduction of $\mathrm{ACh}$, which may result from known changes in AD brains, such as reduced choline acetyltransferase (ChAT) and choline uptake, cholinergic neuronal and axonal abnormalities, and degeneration of cholinergic neurons $[5,110]$. These pathological characteristics of AD observed from postmortem brain tissues of AD patients are evident changes at very late stages of the disease. Some late stage changes may not necessarily reveal or reflect more causative alterations that occur early in the disease process. For example, activity of cholinergic markers, such as ChAT and acetylcholinesterase (AChE), do not decrease until very late stages of the disease [113]. Since neither ChAT nor AChE is ratelimiting, changes in these markers do not necessarily reflect cholinergic function [114]. In fact, ChAT can be inhibited up to $90 \%$ with no measurable effects on $\mathrm{ACh}$ synthesis or release [107], while pharmacological and neurophysiological deficits in cholinergic response can exist without significant changes in ChAT activity during normal aging [114]. In line with the latter situation, we have previously shown that cholinergic hypofunction (reduced $\mathrm{ACh}$ release) can exist in the absence of cholinergic structural degeneration in young GRK5KO mice [42], and this only turns into a cholinergic dysfunction with structural degenerative changes in aged GRK5KO mice [41]. We have thus questioned whether early nonstructural cholinergic dysfunction that precedes the structural cholinergic dysfunction/degeneration could also be causative for the latter [42].

While recognizing the importance of the GRK5 deficiency in $\mathrm{AD}$, many important questions remain to be specifically addressed. Based on existing literature information and our own evidence, we present a hypothetic model that links GRK5 deficiency to the amyloid and cholinergic hypotheses in AD (Figure 3). This hypothetic model attempts to integrate the two most important hypotheses in AD into one unifying hypothesis, in hope to encourage more investigations for validations and for ultimately improving our understanding of the disease pathogenesis. From therapeutic perspective, moreover, it emphasizes the presynaptic autoreceptors as the key target for breaking the vicious cycle between $\mathrm{A} \beta$ and cholinergic dysfunction. 


\section{CONCLUSION}

As described, GRK5 deficiency emerges to become a critical player in $\mathrm{AD}$ pathogenesis, not only due to its close relation to $\mathrm{A} \beta$, but also because of its selective effect on cholinergic dysfunction. Just like Parkinson's disease is marked with dopaminergic neurodegeneration, $\mathrm{AD}$ as a neurodegenerative disorder is labelled with cholinergic selective neurodegeneration. Yet, neurotoxic factors identified as far, including $\mathrm{A} \beta$, are not necessarily more toxic to cholinergic neurons than to non-cholinergic neurons; whereas all the non-selective neurodegenerative forces (i.e., $\mathrm{A} \beta$, oxidative and inflammatory damages) in $\mathrm{AD}$ convert to cholinergic selective neurotoxicity is likely determined by the GRK5 deficiency. For proof-ofthe-principle, the immediate future effort should address whether or not blocking the presynaptic M2 hyperactivity abolishes all the pathologic events driven by the GRK5 deficiency.

\section{ACKNOWLEDGEMENTS}

This work was supported by grants to W.Z.S. from the Medical Research and Development Service, Department of Veterans Affairs, the Alzheimer's Association, and resources from the Midwest Biomedical Research Foundation.

\section{REFERENCES}

[1] Duyckaerts, C., Delatour, B. and Potier, M.C. (2009) Classification and basic pathology of Alzheimer disease. Acta neuropathologica, 118, 5-36. http://dx.doi.org/10.1007/s00401-009-0532-1

[2] Nelson, P.T., Braak, H. and Markesbery, W.R. (2009) Neuropathology and cognitive impairment in Alzheimer disease: A complex but coherent relationship. Journal of Neuropathology and Experimental Neurology, 68, 1-14. http://dx.doi.org/10.1097/NEN.0b013e3181919a48

[3] Jellinger, K.A. and Bancher, C. (1998) Neuropathology of Alzheimer's disease: A critical update. Journal of neural transmission. Supplementum, 54, 77-95. http://dx.doi.org/10.1007/978-3-7091-7508-8 8

[4] Mahler, M.E. and Cummings, J.L. (1990) Alzheimer disease and the dementia of Parkinson disease: Comparative investigations. Alzheimer Disease and Associated Disorders, 4, 133-149. http://dx.doi.org/10.1097/00002093-199040300-00002

[5] Bartus, R.T., Dean 3rd, R.L., Beer, B. and Lippa, A.S. (1982) The cholinergic hypothesis of geriatric memory dysfunction. Science, 217, 408-414.

http://dx.doi.org/10.1126/science.7046051

[6] Hardy, J. and Selkoe, D.J. (2002) The amyloid hypothesis of Alzheimer's disease: Progress and problems on the road to therapeutics. Science, 297, 353-356. http://dx.doi.org/10.1126/science.1072994

[7] Zatta, P.F. (1995) Aluminum binds to the hyperphosphorylated tau in Alzheimer's disease: A hypothesis. Medical
Hypotheses, 44, 169-172.

http://dx.doi.org/10.1016/0306-9877(95)90131-0

[8] Hoyer, S. (2000) Brain glucose and energy metabolism abnormalities in sporadic Alzheimer disease. Causes and consequences: An Update. Experimental Gerontology, 35, 1363-1372.

http://dx.doi.org/10.1016/S0531-5565(00)00156-X

[9] Aisen, P.S. (1996) Inflammation and Alzheimer disease. Molecular and Chemical Neuropathology, 28, 83-88.

[10] McGeer, E.G. and McGeer, P.L. (1999) Brain inflammation in Alzheimer disease and the therapeutic implications. Current Pharmaceutical Design, 5, 821-836.

[11] Blennow, K., Wallin, A., Uhlemann, C. and Gottfries, C.G. (1991) White-matter lesions on CT in Alzheimer patients: Relation to clinical symptomatology and vascular factors. Acta Neurologica Scandinavica, 83, 187-193. http://dx.doi.org/10.1111/j.1600-0404.1991.tb04675.x

[12] Smith, M.A., Richey, P.L., Kalaria, R.N. and Perry, G. (1996) Elastase is associated with the neurofibrillary pathology of Alzheimer disease: A putative link between proteolytic imbalance and oxidative stress. Restorative Neurology and Neuroscience, 9, 213-217.

[13] Pappolla, M.A., Sos, M., Omar, R.A. and Sambamurti, K. (1996) The heat shock/oxidative stress connection. Relevance to Alzheimer disease. Molecular and Chemical Neuropathology, 28, 21-34.

[14] Hoyer, S. (1998) Is sporadic Alzheimer disease the brain type of non-insulin dependent diabetes mellitus? A challenging hypothesis. Journal of Neural Transmission, 105, 415-422. http://dx.doi.org/10.1007/s007020050067

[15] Supnet, C. and Bezprozvanny, I. (2010) The dysregulation of intracellular calcium in Alzheimer disease. Cell Calcium, 47, 183-189. http://dx.doi.org/10.1016/j.ceca.2009.12.014

[16] Sallese, M., Mariggio, S., Collodel, G., Moretti, E., Piomboni, P., Baccetti, B. and De Blasi, A. (1997) G proteincoupled receptor kinase GRK4. Molecular analysis of the four isoforms and ultrastructural localization in spermatozoa and germinal cells. The Journal of Biological Chemistry, 272, 10188-10195. http://dx.doi.org/10.1074/jbc.272.15.10188

[17] Virlon, B., Firsov, D., Cheval, L., Reiter, E., Troispoux, C., Guillou, F. and Elalouf, J.M. (1998) Rat G proteincoupled receptor kinase GRK4: Identification, functional expression, and differential tissue distribution of two splice variants. Endocrinology, 139, 2784-2795. http://dx.doi.org/10.1210/en.139.6.2784

[18] Sallese, M., Salvatore, L., D’Urbano, E., Sala, G., Storto, M., Launey, T., Nicoletti, F., Knopfel, T. and De Blasi, A. (2000) The G-protein-coupled receptor kinase GRK4 mediates homologous desensitization of metabotropic glutamate receptor 1. The FASEB Journal, 14, 2569-2580. http://dx.doi.org/10.1096/fj.00-0072com

[19] Pitcher, J.A., Freedman, N.J. and Lefkowitz, R.J. (1998) $\mathrm{G}$ protein-coupled receptor kinases. Annual Review of Biochemistry, 67, 653-692. http://dx.doi.org/10.1146/annurev.biochem.67.1.653

[20] Kohout, T.A. and Lefkowitz, R.J. (2003) Regulation of G 
protein-coupled receptor kinases and arrestins during receptor desensitization. Molecular Pharmacology, 63, 918. $\mathrm{http://dx.doi.org/10.1124/mol.63.1.9}$

[21] Ribas, C., Penela, P., Murga, C., Salcedo, A., Garcia-Hoz, C., Jurado-Pueyo, M., Aymerich, I. and Mayor Jr., F. (2007) The G protein-coupled receptor kinase (GRK) interactome: Role of GRKs in GPCR regulation and signalling. Biochimica et Biophysica Acta, 1768, 913-922. http://dx.doi.org/10.1016/j.bbamem.2006.09.019

[22] Reiter, E. and Lefkowitz, R.J. (2006) GRKs and beta-arrestins: Roles in receptor silencing, trafficking and signaling. Trends in Endocrinology and Metabolism: TEM, 17, 159-165.

[23] Kunapuli, P. and Benovic, J.L. (1993) Cloning and expression of GRK5: A member of the G protein-coupled receptor kinase family. Proceedings of the National Academy of Sciences of the United States of America, 90, 5588-5592. http://dx.doi.org/10.1073/pnas.90.12.5588

[24] Premont, R.T., Koch, W.J., Inglese, J. and Lefkowitz, R.J. (1994) Identification, purification, and characterization of GRK5, a member of the family of G protein-coupled receptor kinases. The Journal of Biological Chemistry, 269, 6832-6841.

[25] Erdtmann-Vourliotis, M., Mayer, P., Ammon, S., Riechert, U. and Hollt, V. (2001) Distribution of G-protein-coupled receptor kinase (GRK) isoforms 2, 3, 5 and 6 mRNA in the rat brain, brain research. Molecular Brain Research, 95, 129-137. http://dx.doi.org/10.1016/S0006-8993(01)03046-3

[26] Wu, C.C., Tsai, F.M., Shyu, R.Y., Tsai, Y.M., Wang, C.H. and Jiang, S.Y. (2011) G protein-coupled receptor kinase 5 mediates Tazarotene-induced gene 1-induced growth suppression of human colon cancer cells. BMC Cancer, 11, 175. http://dx.doi.org/10.1186/1471-2407-11-175

[27] Liu, P., Wang, X., Gao, N., Zhu, H., Dai, X., Xu, Y., Ma, C., Huang, L., Liu, Y. and Qin, C. (2010) G protein-coupled receptor kinase 5, overexpressed in the alpha-synuclein up-regulation model of Parkinson's disease, regulates bcl-2 expression. Brain Research, 1307, 134-141. http://dx.doi.org/10.1016/j.brainres.2009.10.036

[28] Ahn, M.J., Lee, K.H., Ahn, J.I., Yu, D.H., Lee, H.S., Choi, J.H., Jang, J.S., Bae, J.M. and Lee, Y.S. (2004) The differential gene expression profiles between sensitive and resistant breast cancer cells to adriamycin by cDNA microarray. Cancer Research and Treatment: Official Journal of Korean Cancer Association, 36, 43-49.

[29] Penela, P., Barradas, M., Alvarez-Dolado, M., Munoz, A. and Mayor Jr., F., (2001) Effect of hypothyroidism on G protein-coupled receptor kinase 2 expression levels in rat liver, lung, and heart. Endocrinology, 142, 987-991. http://dx.doi.org/10.1210/en.142.3.987

[30] Ishizaka, N., Alexander, R.W., Laursen, J.B., Kai, H., Fukui, T., Oppermann, M., Lefkowitz, R.J., Lyons, P.R. and Griendling, K.K. (1997) G protein-coupled receptor kinase 5 in cultured vascular smooth muscle cells and rat aorta. Regulation by angiotensin II and hypertension. The Journal of Biological Chemistry, 272, 32482-32488. http://dx.doi.org/10.1074/jbc.272.51.32482

[31] Fan, J. and Malik, A.B. (2003) Toll-like receptor-4 (TLR4) signaling augments chemokine-induced neutrophil migration by modulating cell surface expression of chemokine receptors. Nature Medicine, 9, 315-321.

http://dx.doi.org/10.1038/nm832

[32] Keys, J.R., Zhou, R.H., Harris, D.M., Druckman, C.A. and Eckhart, A.D. (2005) Vascular smooth muscle overexpression of $\mathrm{G}$ protein-coupled receptor kinase 5 elevates blood pressure, which segregates with sex and is dependent on Gi-mediated signalling. Circulation, 112, 1145-1153.

http://dx.doi.org/10.1161/CIRCULATIONAHA.104.5316 $\underline{57}$

[33] Rockman, H.A., Choi, D.J., Rahman, N.U., Akhter, S.A., Lefkowitz, R.J. and Koch, W.J. (1996) Receptor-specific in vivo desensitization by the $\mathrm{G}$ protein-coupled receptor kinase-5 in transgenic mice. Proceedings of the National Academy of Sciences of the United States of America, 93, 9954-9959. http://dx.doi.org/10.1073/pnas.93.18.9954

[34] Cao, T.T., Deacon, H.W., Reczek, D., Bretscher, A. and von Zastrow, M. (1999) A kinase-regulated PDZ-domain interaction controls endocytic sorting of the beta2-adrenergic receptor. Nature, 401, 286-290.

http://dx.doi.org/10.1038/45816

[35] Iwata, M., Yoshikawa, T., Baba, A., Anzai, T., Nakamura, I., Wainai, Y., Takahashi, T. and Ogawa, S. (2001) Autoimmunity against the second extracellular loop of beta(1)adrenergic receptors induces beta-adrenergic receptor desensitization and myocardial hypertrophy in vivo. Circulation Research, 88, 578-586. http://dx.doi.org/10.1161/01.RES.88.6.578

[36] Hu, L.A., Chen, W., Premont, R.T., Cong, M. and Lefkowitz, R.J. (2002) G protein-coupled receptor kinase 5 regulates $\beta_{1}$-adrenergic receptor association with PSD-95, The Journal of Biological Chemistry, 277, 1607-1613. http://dx.doi.org/10.1074/jbc.M107297200

[37] Pei, G., Kieffer, B.L., Lefkowitz, R.J. and Freedman, N.J. (1995) Agonist-dependent phosphorylation of the mouse delta-opioid receptor: Involvement of $\mathrm{G}$ protein-coupled receptor kinases but not protein kinase C. Molecular Pharmacology, 48, 173-177.

[38] Gainetdinov, R.R., Bohn, L.M., Walker, J.K., Laporte, S.A., Macrae, A.D., Caron, M.G., Lefkowitz, R.J. and Premont, R.T. (1999) Muscarinic supersensitivity and impaired receptor desensitization in $\mathrm{G}$ protein-coupled receptor kinase 5-deficient mice. Neuron, 24, 1029-1036. http://dx.doi.org/10.1016/S0896-6273(00)81048-X

[39] Walker, J.K.L., Gainetdinov, R.R., Feldman, D.S., McFawn, P.K., Caron, M.G., Lefkowitz, R.J., Premont, R.T. and Fisher, J.T. (2004) G protein-coupled receptor kinase 5 regulates airway responses induced by muscarinic recaptor activation. American Journal of Physiology-Lung Cellular and Molecular Physiology, 286, L312-L319. http://dx.doi.org/10.1152/ajplung.00255.2003

[40] Suo, Z., Wu, M., Citron, B.A., Wong, G.T. and Festoff, B.W. (2004) Abnormality of G-protein-coupled receptor kinases at prodromal and early stages of Alzheimer's disease: An association with early beta-amyloid accumulation. The Journal of Neuroscience: The Official Journal of the Society for Neuroscience, 24, 3444-3452. 
[41] Suo, Z., Cox, A.A., Bartelli, N., Rasul, I., Festoff, B.W., Premont, R.T. and Arendash, G.W. (2007) GRK5 deficiency leads to early Alzheimer-like pathology and working memory impairment. Neurobiology of Aging, 28, 1873-1888. http://dx.doi.org/10.1016/j.neurobiolaging.2006.08.013

[42] Liu, J., Rasul, I., Sun, Y., Wu, G., Li, L., Premont, R.T. and Suo, W.Z. (2009) GRK5 deficiency leads to reduced hippocampal acetylcholine level via impaired presynaptic M2/M4 autoreceptor desensitization. The Journal of Biological Chemistry, 284, 19564-19571.

http://dx.doi.org/10.1074/jbc.M109.005959

[43] Cheng, S., Li, L., He, S., Liu, J., Sun, Y., He, M., Grasing, K., Premont, R.T. and Suo, W.Z. (2010) GRK5 deficiency accelerates \{beta\}-amyloid accumulation in Tg2576 mice via impaired cholinergic activity. The Journal of Biological Chemistry, 285, 41541-41548. http://dx.doi.org/10.1074/jbc.M110.170894

[44] Arawaka, S., Wada, M., Goto, S., Karube, H., Sakamoto, M., Ren, C.H., Koyama, S., Nagasawa, H., Kimura, H., Kawanami, T., Kurita, K., Tajima, K., Daimon, M., Baba, M., Kido, T., Saino, S., Goto, K., Asao, H., Kitanaka, C., Takashita, E., Hongo, S., Nakamura, T., Kayama, T., Suzuki, Y., Kobayashi, K., Katagiri, T., Kurokawa, K., Kurimura, M., Toyoshima, I., Niizato, K., Tsuchiya, K., Iwatsubo, T., Muramatsu, M., Matsumine, H. and Kato, T. (2006) The role of G-protein-coupled receptor kinase 5 in pathogenesis of sporadic Parkinson's disease. The Journal of Neuroscience: The Official Journal of the Society for Neuroscience, 26, 9227-9238.

[45] Pronin, A.N., Morris, A.J., Surguchov, A. and Benovic, J.L. (2000) Synucleins are a novel class of substrates for $\mathrm{G}$ protein-coupled receptor kinases. The Journal of Biological Chemistry, 275, 26515-26522. http://dx.doi.org/10.1074/jbc.M003542200

[46] Carman, C.V., Som, T., Kim, C.M. and Benovic, J.L. (1998) Binding and phosphorylation of tubulin by G protein-coupled receptor kinases. The Journal of biological chemistry, 273, 20308-20316. http://dx.doi.org/10.1074/jbc.273.32.20308

[47] Chen, X., Zhu, H., Yuan, M., Fu, J., Zhou, Y. and Ma, L. (2010) G-protein-coupled receptor kinase 5 phosphorylates p53 and inhibits DNA damage-induced apoptosis. The Journal of Biological Chemistry, 285, 12823-12830. http://dx.doi.org/10.1074/jbc.M109.094243

[48] Sorriento, D., Ciccarelli, M., Santulli, G., Campanile, A., Altobelli, G.G., Cimini, V., Galasso, G., Astone, D., Piscione, F., Pastore, L., Trimarco, B. and Iaccarino, G. (2008) The G-protein-coupled receptor kinase 5 inhibits NFkappaB transcriptional activity by inducing nuclear accumulation of I $\mathrm{K} \mathrm{B} \alpha$. Proceedings of the National Academy of Sciences of the United States of America, 105, 17818-17823. http://dx.doi.org/10.1073/pnas.0804446105

[49] Sorriento, D., Campanile, A., Santulli, G., Leggiero, E., Pastore, L., Trimarco, B. and Iaccarino, G. (2009) A new synthetic protein, TAT-RH, inhibits tumor growth through the regulation of NFKB activity. Molecular Cancer, 8, 97. http://dx.doi.org/10.1186/1476-4598-8-97

[50] Zhou, R.H., Pesant, S., Cohn, H.I., Soltys, S., Koch, W.J. and Eckhart, A.D. (2009) Negative regulation of VEGF signaling in human coronary artery endothelial cells by $\mathrm{G}$ protein-coupled receptor kinase 5. Clinical and Translational Science, 2, 57-61. http://dx.doi.org/10.1111/j.1752-8062.2008.00058.x

[51] Johnson, L.R., Scott, M.G. and Pitcher, J.A. (2004) G protein-coupled receptor kinase 5 contains a DNA-binding nuclear localization sequence. Molecular and Cellular Biology, 24, 10169-10179.

http://dx.doi.org/10.1128/MCB.24.23.10169-10179.2004

[52] Kara, E., Crepieux, P., Gauthier, C., Martinat, N., Piketty, V., Guillou, F. and Reiter, E. (2006) A phosphorylation cluster of five serine and threonine residues in the C-terminus of the follicle-stimulating hormone receptor is important for desensitization but not for $\beta$-arrestin-mediated ERK activation. Molecular Endocrinology, 20, 30143026. http://dx.doi.org/10.1210/me.2006-0098

[53] Warabi, K., Richardson, M.D., Barry, W.T., Yamaguchi, K., Roush, E.D., Nishimura, K. and Kwatra, M.M. (2002) Human substance $\mathrm{P}$ receptor undergoes agonist-dependent phosphorylation by $\mathrm{G}$ protein-coupled receptor kinase 5 in Vitro. FEBS Letters, 521, 140-144. http://dx.doi.org/10.1016/S0014-5793(02)02858-2

[54] Tiruppathi, C., Yan, W., Sandoval, R., Naqvi, T., Pronin, A.N., Benovic, J.L. and Malik, A.B. (2000) G proteincoupled receptor kinase-5 regulates thrombin-activated signaling in endothelial cells. Proceedings of the National Academy of Sciences of the United States of America, 97, 7440-7445.

http://dx.doi.org/10.1073/pnas.97.13.7440

[55] Nagayama, Y., Tanaka, K., Namba, H., Yamashita, S. and Niwa, M. (1996) Expression and regulation of G proteincoupled receptor kinase 5 and $\beta$-arrestin- 1 in rat thyroid FRTL5 cells. Thyroid, 6, 627-631. http://dx.doi.org/10.1089/thy.1996.6.627

[56] Nagayama, Y., Tanaka, K., Hara, T., Namba, H., Yamashita, S., Taniyama, K. and Niwa, M. (1996) Involvement of $\mathrm{G}$ protein-coupled receptor kinase 5 in homologous desensitization of the thyrotropin receptor. The Journal of Biological Chemistry, 271, 10143-10148. http://dx.doi.org/10.1074/jbc.271.17.10143

[57] Martini, J.S., Raake, P., Vinge, L.E., DeGeorge Jr., B.R., Chuprun, J.K., Harris, D.M., Gao, E., Eckhart, A.D., Pitcher, J.A. and Koch, W.J. (2008) Uncovering G protein-coupled receptor kinase- 5 as a histone deacetylase kinase in the nucleus of cardiomyocytes. Proceedings of the National Academy of Sciences of the United States of America, 105, 12457-12462.

http://dx.doi.org/10.1073/pnas.0803153105

[58] Barker, B.L. and Benovic, J.L. (2011) G protein-coupled receptor kinase 5 phosphorylation of hip regulates internalization of the chemokine receptor CXCR4. Biochemistry, 50, 6933-6941. http://dx.doi.org/10.1021/bi2005202

[59] Parameswaran, N., Pao, C.S., Leonhard, K.S., Kang, D.S., Kratz, M., Ley, S.C. and Benovic, J.L. (2006) Arrestin-2 and $\mathrm{G}$ protein-coupled receptor kinase 5 interact with NFKB1 p105 and negatively regulate lipopolysaccharidestimulated ERK1/2 activation in macrophages. The Journal of Biological Chemistry, 281, 34159-34170. 
http://dx.doi.org/10.1074/jbc.M605376200

[60] Patial, S., Shahi, S., Saini, Y., Lee, T., Packiriswamy, N., Appledorn, D.M., Lapres, J.J., Amalfitano, A. and Parameswaran, N. (2011) G-protein coupled receptor kinase 5 mediates lipopolysaccharide-induced NFKB activation in primary macrophages and modulates inflammation in Vivo in mice. Journal of Cellular Physiology, 226, 1323-1333. http://dx.doi.org/10.1002/jcp.22460

[61] Cai, X., Wu, J.H., Exum, S.T., Oppermann, M., Premont, R.T., Shenoy, S.K. and Freedman, N.J. (2009) Reciprocal regulation of the platelet-derived growth factor receptor- $\beta$ and $\mathrm{G}$ protein-coupled receptor kinase 5 by cross-phosphorylation: Effects on catalysis. Molecular Pharmacology, 75, 626-636.

http://dx.doi.org/10.1124/mol.108.050278

[62] Wu, J.H., Goswami, R., Cai, X., Exum, S.T., Huang, X., Zhang, L., Brian, L., Premont, R.T., Peppel, K. and Freedman, N.J. (2006) Regulation of the platelet-derived growth factor receptor- $\beta$ by $\mathrm{G}$ protein-coupled receptor kinase- 5 in vascular smooth muscle cells involves the phosphatase Shp2. The Journal of Biological Chemistry, 281, 3775837772. http://dx.doi.org/10.1074/jbc.M605756200

[63] Luo, X., Ding, L., Xu, J., Williams, R.S. and Chegini, N. (2005) Leiomyoma and myometrial gene expression profiles and their responses to gonadotropin-releasing hormone analog therapy. Endocrinology, 146, 1074-1096. http://dx.doi.org/10.1210/en.2004-1384

[64] Fan, X., Zhang, J., Zhang, X., Yue, W. and Ma, L. (2002) Acute and chronic morphine treatments and morphine withdrawal differentially regulate GRK2 and GRK5 gene expression in rat brain. Neuropharmacology, 43, 809-816. http://dx.doi.org/10.1016/S0028-3908(02)00147-8

[65] Suo, W.Z. and Li, L. (2010) Dysfunction of G proteincoupled receptor kinases in Alzheimer's disease. The Scientific World Journal, 10, 1667-1678. http://dx.doi.org/10.1100/tsw.2010.154

[66] Pitcher, J.A., Fredericks, Z.L., Stone, W.C., Premont, R.T., Stoffel, R.H., Koch, W.J. and Lefkowitz, R.J. (1996) Phosphatidylinositol 4,5-bisphosphate (PIP2)-enhanced G protein-coupled receptor kinase (GRK) activity: Location, structure, and regulation of the PIP2 binding site distinguishes the GRK subfamilies. The Journal of Biological Chemistry, 271, 24907-24913. http://dx.doi.org/10.1074/jbc.271.40.24907

[67] Pronin, A.N., Satpaev, D.K., Slepak, V.Z. and Benovic, J.L. (1997) Regulation of G protein-coupled receptor kinases by calmodulin and localization of the calmodulin binding domain. The Journal of Biological Chemistry, 272, 18273-18280.

http://dx.doi.org/10.1074/jbc.272.29.18273

[68] Jaber, M., Koch, W.J., Rockman, H., Smith, B., Bond, R.A., Sulik, K.K., Ross, J., Jr., Lefkowitz, R.J., Caron, M.G. and Giros, B. (1996) Essential role of $\beta$-adrenergic receptor kinase 1 in cardiac development and function. Proceedings of the National Academy of Sciences of the United States of America, 93, 12974-12979. http://dx.doi.org/10.1073/pnas.93.23.12974

[69] Peppel, K., Boekhoff, I., McDonald, P., Breer, H., Caron, M.G. and Lefkowitz, R.J. (1997) G protein-coupled re- ceptor kinase 3 (GRK3) gene disruption leads to loss of odorant receptor desensitization. The Journal of Biological Chemistry, 272, 25425-25428. http://dx.doi.org/10.1074/jbc.272.41.25425

[70] Gainetdinov, R.R., Bohn, L.M., Sotnikova, T.D., Cyr, M., Laakso, A., Macrae, A.D., Torres, G.E., Kim, K.M., Lefkowitz, R.J., Caron, M.G. and Premont, R.T. (2003) Dopaminergic supersensitivity in $\mathrm{g}$ protein-coupled receptor kinase 6-deficient mice. Neuron, 38, 291-303. http://dx.doi.org/10.1016/S0896-6273(03)00192-2

[71] Matsui, M., Yamada, S., Oki, T., Manabe, T., Taketo, M.M. and Ehlert, F.J. (2004) Functional analysis of muscarinic acetylcholine receptors using knockout mice. Life Sciences, 75, 2971-2981. http://dx.doi.org/10.1016/j.1fs.2004.05.034

[72] Wess, J. (2004) Muscarinic acetylcholine receptor knockout mice: Novel phenotypes and clinical implications. Annual Review of Pharmacology and Toxicology, 44, 423450.

http://dx.doi.org/10.1146/annurev.pharmtox.44.101802.12 $\underline{1622}$

[73] Hsiao, K., Chapman, P., Nilsen, S., Eckman, C., Harigaya, Y., Younkin, S., Yang, F. and Cole, G. (1996) Correlative memory deficits, $\mathrm{A} \beta$ elevation, and amyloid plaques in transgenic mice. Science, 274, 99-103. http://dx.doi.org/10.1126/science.274.5284.99

[74] Li, L., Liu, J. and Suo, W.Z. (2008) GRK5 deficiency exaggerates inflammatory changes in TgAPPsw mice. Journal of Neuroinflammation, 5, 24. http://dx.doi.org/10.1186/1742-2094-5-24

[75] Le, Y., Gong, W., Tiffany, H.L., Tumanov, A., Nedospasov, S., Shen, W., Dunlop, N.M., Gao, J.L., Murphy, P.M., Oppenheim, J.J. and Wang, J.M. (2001) Amyloid (beta)42 activates a G-protein-coupled chemoattractant receptor, FPR-like-1. The Journal of Neuroscience: The Official Journal of the Society for Neuroscience, 21, RC123.

[76] Yazawa, H., Yu, Z.X., Takeda, Le, Y., Gong, W., Ferrans, V.J., Oppenheim, J.J., Li, C.C. and Wang, J.M. (2001) $\beta$ amyloid peptide (A $\beta 42)$ is internalized via the G-proteincoupled receptor FPRL1 and forms fibrillar aggregates in macrophages. The FASEB Journal, 15, 2454-2462. http://dx.doi.org/10.1096/fj.01-0251com

[77] Langkabel, P., Zwirner, J. and Oppermann, M. (1999) Ligand-induced phosphorylation of anaphylatoxin recaptors $\mathrm{C} 3 \mathrm{aR}$ and $\mathrm{C} 5 \mathrm{aR}$ is mediated by $\mathrm{G}$ protein-coupled receptor kinases. European Journal of Immunology, 29, 3035-3046.

http://dx.doi.org/10.1002/(SICI)1521-4141(199909)29:09 $\leq 3035::$ AID-IMMU3035>3.0.CO;2-Z

[78] Streit, W.J., Conde, J.R. and Harrison, J.K. (2001) Chemokines and Alzheimer's disease. Neurobiology of Aging, 22, 909-913.

http://dx.doi.org/10.1016/S0197-4580(01)00290-1

[79] Levey, A.I. (1996) Muscarinic acetylcholine receptor expression in memory circuits: Implications for treatment of Alzheimer disease. Proceedings of the National Academy of Sciences of the United States of America, 93, 13541-13546. http://dx.doi.org/10.1073/pnas.93.24.13541

[80] Zhang, W., Basile, A.S., Gomeza, J., Volpicelli, L.A., 
Levey, A.I. and Wess, J. (2002) Characterization of central inhibitory muscarinic autoreceptors by the use of muscarinic acetylcholine receptor knock-out mice. The Journal of Neuroscience: The Official Journal of the Society for Neuroscience, 22, 1709-1717.

[81] Rossner, S., Ueberham, U., Schliebs, R., Perez-Polo, J.R. and Bigl, V. (1998) The regulation of amyloid precursor protein metabolism by cholinergic mechanisms and neuro-trophin receptor signalling. Progress in Neurobiology, 56, 541-569. http://dx.doi.org/10.1016/S0301-0082(98)00044-6

[82] DeLapp, N., Wu, S., Belagaje, R., Johnstone, E., Little, S., Shannon, H., Bymaster, F., Calligaro, D., Mitch, C., Whitesitt, C., Ward, J., Sheardown, M., Fink-Jensen, A., Jeppesen, L., Thomsen, C. and Sauerberg, P. (1998) Effects of the M1 agonist xanomeline on processing of human $\beta$-amyloid precursor protein (FAD, Swedish mutant) transfected into Chinese hamster ovary-m1 cells. Biochemical and Biophysical Research Communications, 244, 156-160. http://dx.doi.org/10.1006/bbrc.1998.8235

[83] Lin, L., Georgievska, B., Mattsson, A. and Isacson, O. (1999) Cognitive changes and modified processing of amyloid precursor protein in the cortical and hippocampal system after cholinergic synapse loss and muscarinic receptor activation. Proceedings of the National Academy of Sciences of the United States of America, 96, 1210812113. http://dx.doi.org/10.1073/pnas.96.21.12108

[84] Fisher, A., Pittel, Z., Haring, R., Bar-Ner, N., Kliger-Spatz, M., Natan, N., Egozi, I., Sonego, H., Marcovitch, I. and Brandeis, R. (2003) M1 muscarinic agonists can modulate some of the hallmarks in Alzheimer's disease: Implications in future therapy. Journal of Molecular Neuroscience, 20, 349-356.

http://dx.doi.org/10.1385/JMN:20:3:349

[85] Liskowsky, W. and Schliebs, R. (2006) Muscarinic acetylcholine receptor inhibition in transgenic Alzheimer-like Tg2576 mice by scopolamine favours the amyloidogenic route of processing of amyloid precursor protein. International Journal of Developmental Neuroscience, 24, 149156. http://dx.doi.org/10.1016/j.ijdevneu.2005.11.010

[86] Budd, D.C., McDonald, J., Emsley, N., Cain, K. and Tobin, A.B. (2003) The C-terminal tail of the M3-muscarinic receptor possesses anti-apoptotic properties. The Journal of Biological Chemistry, 278, 19565-19573. http://dx.doi.org/10.1074/jbc.M211670200

[87] Postina, R. (2008) A closer look at alpha-secretase. Current Alzheimer research, 5, 179-186. http://dx.doi.org/10.2174/156720508783954668

[88] Sadot, E., Gurwitz, D., Barg, J., Behar, L., Ginzburg, I. and Fisher, A. (1996) Activation of $\mathrm{m} 1$ muscarinic acetylcholine receptor regulates tau phosphorylation in transfected PC12 cells. Journal of Neurochemistry, 66, 877880.

http://dx.doi.org/10.1046/j.1471-4159.1996.66020877.x

[89] Pemberton, K.E., Hill-Eubanks, L.J. and Jones, S.V. (2000) Modulation of low-threshold T-type calcium channels by the five muscarinic receptor subtypes in NIH $3 \mathrm{~T} 3$ cells. Pflügers Archiv, 440, 452-461. http://dx.doi.org/10.1007/s004240000303
[90] Crespo, P., Xu, N., Simonds, W.F. and Gutkind, J.S. (1994) Ras-dependent activation of MAP kinase pathway mediated by G-protein beta gamma subunits. Nature, 369, 418420. http://dx.doi.org/10.1038/369418a0

[91] Kim, S.S., Choi, J.M., Kim, J.W., Ham, D.S., Ghil, S.H., Kim, M.K., Kim-Kwon, Y., Hong, S.Y., Ahn, S.C., Kim, S.U., Lee, Y.D., Suh-Kim, H. (2005) cAMP induces neuronal differentiation of mesenchymal stem cells via activetion of extracellular signal-regulated kinase/MAPK. Neuroreport, 16, 1357-1361. http://dx.doi.org/10.1097/01.wnr.0000175243.12966.f5

[92] Kiermayer, S., Biondi, R.M., Imig, J., Plotz, G., Haupenthal, J., Zeuzem, S. and Piiper, A. (2005) Epac activation converts cAMP from a proliferative into a differentiation signal in PC12 cells. Molecular Biology of the Cell, 16, 5639-5648. http://dx.doi.org/10.1091/mbc.E05-05-0432

[93] Malbon, C.C., Tao, J. and Wang, H.Y. (2004) AKAPs (A-kinase anchoring proteins) and molecules that compose their G-protein-coupled receptor signalling complexes. Biochemical Journal, 379, 1-9. http://dx.doi.org/10.1042/BJ20031648

[94] Tasken, K. and Aandahl, E.M. (2004) Localized effects of cAMP mediated by distinct routes of protein kinase A. Physiological Reviews, 84, 137-167. http://dx.doi.org/10.1152/physrev.00021.2003

[95] Dumaz, N. and Marais, R. (2005) Integrating signals between cAMP and the RAS/RAF/MEK/ERK signalling pathways. Based on the anniversary prize of the Gesellschaft fur Biochemie und Molekularbiologie Lecture delivered on 5 July 2003 at the Special FEBS Meeting in Brussels. FEBS Journal, 272, 3491-3504. http://dx.doi.org/10.1111/j.1742-4658.2005.04763.x

[96] Chin, P.C., Majdzadeh, N. and D’Mello, S.R. (2005) Inhibition of GSK3 $\beta$ is a common event in neuroprotection by different survival factors, Brain research. Molecular Brain Research, 137, 193-201. http://dx.doi.org/10.1016/j.molbrainres.2005.03.004

[97] Fang, X., Yu, S.X., Lu, Y., Bast, R.C., Jr., Woodgett, J.R. and Mills, G.B. (2000) Phosphorylation and inactivation of glycogen synthase kinase 3 by protein kinase A. Proceedings of the National Academy of Sciences of the United States of America, 97, 11960-11965. http://dx.doi.org/10.1073/pnas.220413597

[98] Buller, C.L., Loberg, R.D., Fan, M.H., Zhu, Q., Park, J.L., Vesely, E., Inoki, K., Guan, K.L. and Brosius III, F.C. (2008) A GSK-3/TSC2/mTOR pathway regulates glucose

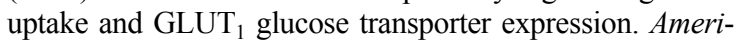
can Journal of Physiology-Cell Physiology, 295, C836C843. http://dx.doi.org/10.1152/ajpcell.00554.2007

[99] Zhao, Y., Altman, B.J., Coloff, J.L., Herman, C.E., Jacobs, S.R., Wieman, H.L., Wofford, J.A., Dimascio, L.N., Ilkayeva, O., Kelekar, A., Reya, T. and Rathmell, J.C. (2007) Glycogen synthase kinase $3 \alpha$ and $3 \beta$ mediate a glucosesensitive antiapoptotic signaling pathway to stabilize Mcl-1. Molecular and Cellular Biology, 27, 4328-4339. http://dx.doi.org/10.1128/MCB.00153-07

[100] Hur, E.M. and Zhou, F.Q. (2010) GSK3 signalling in neural development. Nature Reviews. Neuroscience, 11, 539551. http://dx.doi.org/10.1038/nrn2870 
[101] Imahori, K. and Uchida, T. (1997) Physiology and pathology of tau protein kinases in relation to Alzheimer's disease. Journal of Biochemistry, 121, 179-188.

[102] Roy, S., Zhang, B., Lee, V.M. and Trojanowski, J.Q. (2005) Axonal transport defects: A common theme in neurodegenerative diseases. Acta Neuropathologica, 109, 5-13. http://dx.doi.org/10.1007/s00401-004-0952-x

[103] Trojanowski, J.Q. and Lee, V.M. (1995) Phosphorylation of paired helical filament tau in Alzheimer's disease neurofibrillary lesions: Focusing on phosphatises. FASEB Journal, 9, 1570-1576.

[104] Morfini, G., Szebenyi, G., Elluru, R., Ratner, N. and Brady, S.T. (2002) Glycogen synthase kinase 3 phosphorylates kinesin light chains and negatively regulates kinesin-based motility. The Embo Journal, 21, 281-293. http://dx.doi.org/10.1093/emboj/21.3.281

[105] Stokin, G.B., Lillo, C., Falzone, T.L., Brusch, R.G., Rockenstein, E., Mount, S.L., Raman, R., Davies, P., Masliah, E., Williams, D.S. and Goldstein, L.S. (2005) Axonopathy and transport deficits early in the pathogenesis of Alzheimer's disease. Science, 307, 1282-1288. http://dx.doi.org/10.1126/science.1105681

[106] Thathiah, A. and De Strooper, B. (2009) G protein-coupled receptors, cholinergic dysfunction, and Abeta toxicity in Alzheimer's disease. Science Signaling, 2, re8. http://dx.doi.org/10.1126/scisignal.293re8

[107] Bartus, R.T., Dean, R.L., Pontecorvo, M.J. and Flicker, C. (1985) The cholinergic hypothesis: A historical overview, current perspective, and future directions. Annals of the New York Academy of Sciences, 444, 332-358. http://dx.doi.org/10.1111/j.1749-6632.1985.tb37600.x
[108] Woolf, N.J. (1996) The critical role of cholinergic basal forebrain neurons in morphological change and memory encoding: A hypothesis. Neurobiology of Learning and Memory, 66, 258-266. http://dx.doi.org/10.1006/nlme.1996.0068

[109] Ladner, C.J. and Lee, J.M. (1998) Pharmacological drug treatment of Alzheimer disease: The cholinergic hypothesis revisited. Journal of Neuropathology and Experimental neurology, 57, 719-731. http://dx.doi.org/10.1097/00005072-199808000-00001

[110] Fisher, A. (2008) Cholinergic treatments with emphasis on M1 muscarinic agonists as potential disease-modifying agents for Alzheimer's disease. Neurotherapeutics, 5, 433442. http://dx.doi.org/10.1016/j.nurt.2008.05.002

[111] Small, D.H. and Cappai, R. (2006) Alois Alzheimer and Alzheimer's disease: A centennial perspective. Journal of Neurochemistry, 99, 708-710. http://dx.doi.org/10.1111/j.1471-4159.2006.04212.x

[112] De Strooper, B., Vassar, R. and Golde, T. (2010) The secretases: Enzymes with therapeutic potential in Alzheimer disease. Nature Reviews. Neurology, 6, 99-107. http://dx.doi.org/10.1038/nrneurol.2009.218

[113] Davis, K.L., Mohs, R.C., Marin, D., Purohit, D.P., Perl, D.P., Lantz, M., Austin, G. and Haroutunian, V. (1999) Cholinergic markers in elderly patients with early signs of Alzheimer disease. JAMA, 281, 1401-1406. http://dx.doi.org/10.1001/jama.281.15.1401

[114] Bartus, R.T. and Emerich, D.F. (1999) Cholinergic markers in Alzheimer disease. JAMA, 282, 2208-2209. http://dx.doi.org/10.1001/jama.282.23.2208 